University of Nebraska - Lincoln

DigitalCommons@University of Nebraska - Lincoln

Agronomy \& Horticulture -- Faculty Publications

Agronomy and Horticulture Department

7-2001

\title{
Controlling Nitrate Leaching in Irrigated Agriculture
}

\author{
Roy F. Spalding \\ University of Nebraska-Lincoln, rspalding1@unl.edu \\ Darrell G. Watts \\ University of Nebraska-Lincoln \\ James S. Schepers \\ University of Nebraska-Lincoln, james.schepers@gmail.com \\ Mark E. Burbach \\ University of Nebraska-Lincoln, mburbach1@unl.edu \\ Mary E. Exner \\ University of Nebraska-Lincoln
}

See next page for additional authors

Follow this and additional works at: https://digitalcommons.unl.edu/agronomyfacpub

Part of the Plant Sciences Commons

Spalding, Roy F.; Watts, Darrell G.; Schepers, James S.; Burbach, Mark E.; Exner, Mary E.; Poreda, Robert J.; and Martin, Glen E., "Controlling Nitrate Leaching in Irrigated Agriculture" (2001). Agronomy \& Horticulture -- Faculty Publications. 368.

https://digitalcommons.unl.edu/agronomyfacpub/368

This Article is brought to you for free and open access by the Agronomy and Horticulture Department at DigitalCommons@University of Nebraska - Lincoln. It has been accepted for inclusion in Agronomy \& Horticulture -Faculty Publications by an authorized administrator of DigitalCommons@University of Nebraska - Lincoln. 


\section{Authors}

Roy F. Spalding, Darrell G. Watts, James S. Schepers, Mark E. Burbach, Mary E. Exner, Robert J. Poreda, and Glen E. Martin 


\title{
Controlling Nitrate Leaching in Irrigated Agriculture
}

\author{
Roy F. Spalding,* Darrell G. Watts, James S. Schepers, Mark E. Burbach, \\ Mary E. Exner, Robert J. Poreda, and Glen E. Martin
}

\begin{abstract}
The impact of improved irrigation and nutrient practices on ground water quality was assessed at the Nebraska Management System Evaluation Area using ground water quality data collected from 16 depths at 31 strategically located multilevel samplers three times annually from 1991 to 1996. The site was sectioned into four 13.4-ha management fields: (i) a conventional furrow-irrigated corn (Zea mays L.) field; (ii) a surge-irrigated corn field, which received $60 \%$ less water and $31 \%$ less $\mathbf{N}$ fertilizer than the conventional field; (iii) a center pivot-irrigated corn field, which received $66 \%$ less water and $37 \%$ less $\mathbf{N}$ fertilizer than the conventional field; and (iv) a center pivotirrigated alfalfa (Medicago sativa $\mathrm{L}_{\text {.) }}$ field. Dating $\left({ }^{3} \mathrm{H} /{ }^{3} \mathrm{He}\right.$ ) indicated that the uppermost ground water was $<1$ to $2 \mathrm{yr}$ old and that the aquifer water was stratified with the deepest water $\sim 20 \mathrm{yr}$ old. Recharge during the wet growing season in 1993 reduced the average $\mathrm{NO}_{3}-\mathrm{N}$ concentration in the top $3 \mathrm{~m} 20 \mathrm{mg} \mathrm{L}^{-1}$, effectively diluting and replacing the $\mathrm{NO}_{3}$-contaminated water. Nitrate concentrations in the shallow zone of the aquifer increased with depth to water. Beneath the conventional and surge-irrigated fields, shallow ground water concentrations returned to the initial $30 \mathrm{mg} \mathrm{NO}_{3}-\mathrm{N} \mathrm{L}^{-1}$ level by fall 1995; however, beneath the center pivot-irrigated corn field, concentrations remained at $\sim 13 \mathrm{mg} \mathrm{NO}_{3}-\mathrm{N} \mathrm{L}^{-1}$ until fall 1996. A combination of sprinkler irrigation and $\mathbf{N}$ fertigation significantly reduced $\mathbf{N}$ leaching with only minor reductions $(6 \%)$ in crop yield.
\end{abstract}

R.F. Spalding, Dep. of Agronomy, Univ. of Nebraska, Lincoln, NE 68583-0844; D.G. Watts, Dep. of Biological Systems Eng., Univ. of Nebraska, Lincoln, NE 68583-0726; J.S. Schepers, Dep. of Agronomy USDA-ARS, Univ. of Nebraska, Lincoln, NE 68583-0934; M.E. Burbach and G.E. Martin, Water Sciences Lab., Univ. of Nebraska, Lincoln, NE 68583-0844; M.E. Exner, School of Natural Resource Sciences, Univ. of Nebraska, Lincoln, NE 68583-0759; and R.J. Poreda, Dep. of Earth and Environ. Sciences, Univ. of Rochester, Rochester, NY 14627. Received 2 June 2000. *Corresponding author (rspalding1@unl.edu).

Published in J. Environ. Qual. 30:1184-1194 (2001).
Assessments of ground water $\mathrm{NO}_{3}$ contamination report that many major areas of nonpoint-source contamination are located in the irrigated semiarid and arid regions of the western USA (Madison and Brunett, 1985; Anderson, 1989; Power and Schepers, 1989; Spalding and Exner, 1993). The thrust of these reports provides a clear association between nonpoint-source ground water $\mathrm{NO}_{3}$ contamination and irrigated agriculture.

Irrigated agriculture has a major impact on the economy of several states both in the west and in the western Corn Belt. In Nebraska, 3.4 million ha of irrigated agriculture and related spin-off service industries add approximately $\$ 3$ billion annually to the state's economy. Controlling leachates from irrigated crop land, especially from the 2.3 million ha of irrigated corn, requires fundamental changes in farm practices that not only lead to solutions but are acceptable to producers and regulators. Nebraska's dependence on ground water as the primary source of potable water is the major thrust for a sustained impetus to develop and implement more effective agricultural management strategies to reduce ground water $\mathrm{NO}_{3}$ contamination.

Beginning in 1990, the USDA sponsored Management Systems Evaluation Area (MSEA) projects in five midwestern states in the corn and soybean [Glycine max (L.) Merr.] belt. The projects concentrated both on understanding the mechanisms involved in nonpointsource contamination of surface and ground water by agrochemicals and on developing economically accept-

Abbreviations: MLSs, multilevel samplers; ET, evapotranspiration MSEA, Management Systems Evaluation Area; NE-MSEA, Nebraska MSEA; CPNRD, Central Platte Natural Resources District MCL, maximum contaminant level; DOC, dissolved organic carbon. 
able farming practices that reduce leaching. The $\mathrm{Ne}$ braska MSEA (NE-MSEA) project focused on the impact of irrigated agriculture on ground water quality and the development of methods to mitigate agrochemical leaching in irrigated agriculture.

This paper demonstrates that (i) seasonal responses to agricultural practices can be detected by monitoring shallow ground water quality; (ii) management can impact $\mathrm{NO}_{3}$ loading; and, most importantly, (iii) innovative agricultural practices can maintain $\mathrm{NO}_{3}$ concentrations at more acceptable levels without significantly compromising crop yields. The project was designed to provide regulators and irrigators with research results needed to promote environmentally sound management.

\section{STUDY SITE}

\section{Water Quality and Agricultural Practices}

The principal target area of the NE-MSEA lies within the Central Platte Natural Resources District (CPNRD) in the central Platte River Valley (Fig. 1). It is located within 202000 contiguous hectares underlain by a shallow, $\mathrm{NO}_{3}$-contaminated, sand and gravel aquifer (Spalding and Exner, 1993). Nitrate concentrations within this large zone vary from 10 to $>50 \mathrm{mg} \mathrm{NO}_{3}-\mathrm{N} \mathrm{L}^{-1}$. In this area dominated by furrow-irrigated corn production, most of the contamination is derived from commercial fertilizer leachates (Gormly and Spalding, 1979). While N applications in the 1960s and 1970s ranged from 250 to $300 \mathrm{~kg} \mathrm{ha}^{-1}$, recent surveys suggest that, as a result of educational programs and regulations, most applications have declined to $\sim 150$ to $180 \mathrm{~kg} \mathrm{ha}^{-1}$, although $20 \%$ of the producers continue to apply more than is recommended (Supalla et al., 1995).

In the study area, precipitation and evapotranspiration (ET) during the growing season average 420 and $690 \mathrm{~mm}$, respectively, which resulted in a seasonally dependent net irrigation requirement of 0 to $>450 \mathrm{~mm}$ during the $30 \mathrm{yr}$ ending in 1996 (Martin and Watts, 1997). Although strategies for improved furrow irrigation efficiency have been introduced, the availability of abundant shallow ground water fosters inefficient irrigation practices that promote leaching (Cahoon et al., 1995). Beneath the NE-MSEA and adjacent areas, $\mathrm{NO}_{3}-\mathrm{N}$ concentrations generally range from 30 to 40 $\mathrm{mg} \mathrm{L}^{-1}$ (Spalding et al., 1993).

The NE-MSEA consists of an upgradient buffer area ( $\sim 130 \mathrm{ha})$, a component research site ( $\sim 32 \mathrm{ha})$, and a research/demonstration site $(\sim 54 \mathrm{ha})$. The latter is subdivided into four 13.4-ha management fields. Three are cropped to corn and the fourth to alfalfa (Fig. 2). Each spring the farmer prepared the three corn fields by shredding stalks and tilling twice with a tandem disk harrow. The corn fields received banded applications of atrazine-metolachlor mix $^{1}$ (Bicep) at planting, and $24 \mathrm{~kg} \mathrm{~N} \mathrm{ha}^{-1}$ as UAN were applied with the seed. Each corn management field was subject to different irrigation and $\mathrm{N}$ management practices (Table 1). Applica-

\footnotetext{
${ }^{1}$ Atrazine (2-chloro-4-ethylamino-6-isopropylamino-1,3,5-triazine), metolachlor [2-chloro- $N$-(2-ethyl-6-methylphenyl)- $N$-(2-methoxy-1methylethyl)acetamide].
}

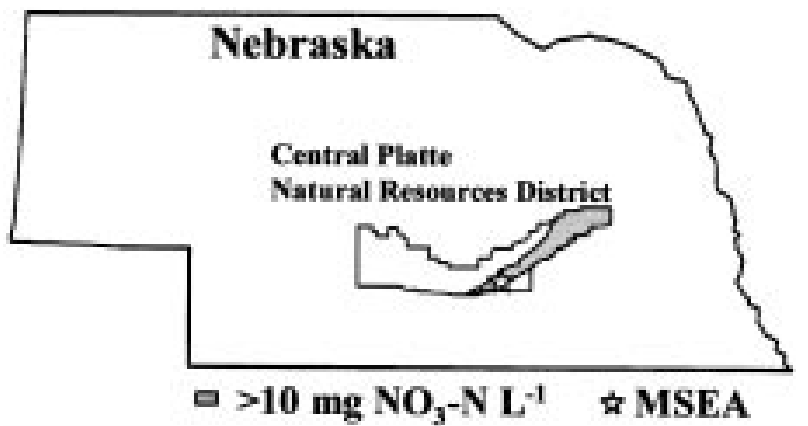

Fig. 1. Location of Central Platte Natural Resources District (NRD), shallow ground water nonpoint $\mathrm{NO}_{3}-\mathrm{N}$ plume, and the Nebraska Management Systems Evaluation Area (NE-MSEA) research/ demonstration site.

tions of $\mathrm{N}$ fertilizer and irrigation water were controlled in the buffer to reduce recharge upgradient of the management fields.

\section{Conventional Furrow-Irrigated Corn Management Field}

The conventional field was managed by the land owner, who applied preplant $\mathrm{NH}_{3}$ and irrigated through gated pipe into furrows using 12-h continuous sets. Irrigation was on an every-furrow basis and runoff water accumulated behind the end-of-field dike (Fig. 2). With the exception of periods of significant precipitation or very cool temperatures, weekly water applications ranged from $\sim 160$ to $200 \mathrm{~mm}$. During the first $2 \mathrm{yr}$ of the project, preplant $\mathrm{NH}_{3}$ was applied without nitrification inhibitor. Subsequent CPNRD regulations required the use of an inhibitor when more than half the seasonal $\mathrm{N}$ application was applied preplant.

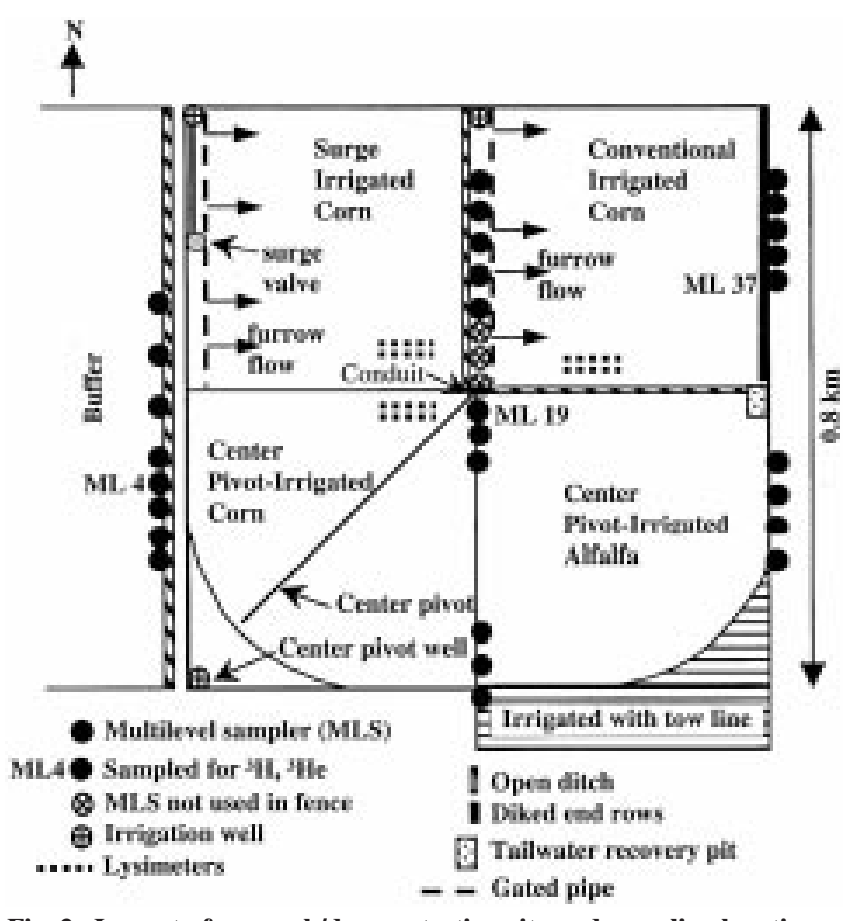

Fig. 2. Layout of research/demonstration site and sampling locations. 
Table 1. Summary of annual precipitation, irrigation, irrigation-applied $\mathbf{N}$, soil $\mathbf{N}$, fertilizer $\mathbf{N}$, and yield data for management fields.

\begin{tabular}{|c|c|c|c|c|c|c|c|c|c|}
\hline $\begin{array}{l}\text { Year/management } \\
\text { field }\end{array}$ & $\begin{array}{l}\text { Precipitation } \\
\text { growing season }\end{array}$ & $\begin{array}{c}\text { Irrigation } \\
\text { water }\end{array}$ & $\begin{array}{l}\text { Annual } \\
\text { precip. }\end{array}$ & Residual N & Preplant N & Starter N & $\begin{array}{l}\text { Sidedress (S) and/or } \\
\text { fertigation (F) N }\end{array}$ & Irrigation $\mathbf{N}$ & $\begin{array}{l}\text { Grain } \\
\text { yield }\end{array}$ \\
\hline & 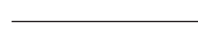 & $\mathbf{m m}$ & - & 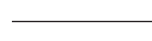 & . & - kg he & -1 & & $\mathrm{Mg} \mathrm{ha}^{-1}$ \\
\hline \multicolumn{10}{|l|}{1991} \\
\hline Conventional & 297 & 942 & 468 & 95 & 180 & 24 & & 288 & 12.51 \\
\hline Surge & 297 & 455 & 468 & 150 & & 24 & 101(S) & 141 & 12.32 \\
\hline Center-pivot corn & 297 & 335 & 468 & 85 & & 24 & & 92 & 12.20 \\
\hline Center-pivot alfalfa & 297 & 328 & 468 & & & & & 88 & \\
\hline \multicolumn{10}{|l|}{1992} \\
\hline Conventional & 319 & 744 & 520 & 108 & 168 & 24 & & 223 & 13.01 \\
\hline Surge & 319 & 231 & 520 & 121 & & 24 & 51(S) & 51 & 12.57 \\
\hline Center-pivot corn & 319 & 208 & 520 & 70 & & 24 & $22(F)$ & 54 & 11.00 \\
\hline Center-pivot alfalfa & 319 & 303 & 520 & & & & & 78 & \\
\hline \multicolumn{10}{|l|}{1993} \\
\hline Conventional & 635 & 203 & 879 & 59 & 168 & 24 & & 64 & 8.93 \\
\hline Surge & 635 & 114 & 879 & 51 & 58 & 24 & 79(F) & 39 & 8.05 \\
\hline Center-pivot corn & 635 & 79 & 879 & 21 & 68 & 24 & $66(F)$ & 24 & 8.17 \\
\hline Center-pivot alfalfa & 635 & 84 & 879 & & & & & 25 & \\
\hline \multicolumn{10}{|l|}{1994} \\
\hline Conventional & 385 & 767 & 542 & 93 & 187 & 24 & & 253 & $8.00 \dagger$ \\
\hline Surge & 385 & 297 & 542 & 97 & 99 & 24 & 55(F) & 99 & $7.98 \dagger$ \\
\hline Center-pivot corn & 385 & 107 & 542 & 68 & 98 & 24 & $38(F)$ & 31 & $7.13 \dagger$ \\
\hline Center-pivot alfalfa & 385 & 396 & 542 & & & & & 115 & \\
\hline \multicolumn{10}{|l|}{1995} \\
\hline Conventional & 377 & 582 & 607 & 106 & 180 & 24 & & 181 & 11.63 \\
\hline Surge & 377 & 264 & 607 & 93 & & 24 & 134(S) & 72 & 11.32 \\
\hline Center-pivot corn & 377 & 307 & 607 & 83 & & 24 & 164(S and F) & 95 & 11.82 \\
\hline Center-pivot alfalfa & 377 & 249 & 607 & & & & & 77 & \\
\hline \multicolumn{10}{|l|}{1996} \\
\hline Conventional & 579 & 1275 & 684 & 74 & 167 & 24 & & 356 & 13.45 \\
\hline Surge & 579 & 241 & 684 & 60 & 80 & 24 & $56(S)$ & 68 & 13.20 \\
\hline Center-pivot corn & 579 & 152 & 684 & 74 & 112 & 24 & 61(S) & 45 & 12.70 \\
\hline Center-pivot alfalfa & 579 & 114 & 684 & & & & & 34 & \\
\hline Management field & & \multicolumn{2}{|c|}{$\begin{array}{c}\text { 6-yr Total } \\
\text { applied water (mm) }\end{array}$} & \multicolumn{3}{|c|}{$\begin{array}{c}\text { 6-yr Total } \\
\text { applied N }\left(\mathrm{kg} \mathrm{ha}^{-1}\right)\end{array}$} & & \multicolumn{2}{|c|}{$\begin{array}{c}\text { 5-yr Avg. } \\
\text { grain yield }\left(\mathrm{Mg} \mathrm{ha}^{-1}\right) \\
\end{array}$} \\
\hline Conventional & & \multicolumn{2}{|c|}{8213} & \multirow{2}{*}{\multicolumn{4}{|c|}{$\begin{array}{l}3094 \\
1899\end{array}$}} & \multicolumn{2}{|c|}{11.91} \\
\hline Surge & & \multirow{2}{*}{\multicolumn{2}{|c|}{$\begin{array}{l}5302 \\
4888\end{array}$}} & & & & & \multirow{2}{*}{\multicolumn{2}{|c|}{$\begin{array}{l}11.49 \\
11.18\end{array}$}} \\
\hline Center-pivot corn & & & & \multicolumn{4}{|c|}{$\begin{array}{l}1899 \\
1515\end{array}$} & & \\
\hline
\end{tabular}

$\dagger$ Not used in average yield calculation.

\section{Surge-Irrigated Corn Management Field}

Surge irrigation provides a more uniform water application than conventional furrow irrigation (Musick et al., 1987) and, therefore, is considered an improved technique. The field was graded using a laser-guided system in fall 1990 to obtain better water distribution on the gently sloping land. Irrigation water was delivered to the surge valve, distributed to furrows on both sides of the surge valve through gated pipe, and conveyed through the furrows with the excess discharged into a ditch at the lower end of the field and then into a lined tailwater recovery pit (Fig. 2). A combination of alternate furrow surge-flow irrigation and runoff recovery is designed to reduce deep percolation and total pumping. Irrigations were scheduled by standard water balance techniques according to ET computed from daily weather data. Typical beginning-of-season net irrigation applications (gross application minus runoff) ranged from 55 to $75 \mathrm{~mm}$. Subsequent applications usually averaged $\sim 50 \mathrm{~mm}$.

During the first, second, and fifth growing seasons, $\mathrm{NH}_{3}$ was applied as sidedress when the crop was in the 4 to 6-leaf stage. In 1993 and 1994, the N application was split between preplant $\mathrm{NH}_{3}$ and UAN solution injected into the irrigation water (fertigation), while in 1996 the application was split between preplant and sidedress $\mathrm{N}$.

\section{Center Pivot-Irrigated Corn Management Field}

Irrigations via a $379-\mathrm{m}$ long center pivot followed the same scheduling technique employed on the surgeirrigated field. Typical irrigation applications were $\sim 25$ $\mathrm{mm}$. After mid-July, a soil-water deficit of $\sim 25 \mathrm{~mm}$ was maintained to provide storage of rainfall, thereby reducing leaching. In late summer, the deficit was gradually increased as the crop matured. This enhanced storage of off-season precipitation reduced the leaching of residual soil $\mathrm{NO}_{3}$ the following spring.

With the exception of the first year, when only starter $\mathrm{N}$ was applied, $\mathrm{N}$ applications were split in 4 of $5 \mathrm{yr}$ between either preplant or early sidedress $\mathrm{NH}_{3}$ and incremental applications of UAN via fertigation. The latter were based on chlorophyll meter readings in the crop canopy (Schepers et al., 1995). In 1992 all the N was applied by fertigation. The approach minimized both the $\mathrm{N}$ application required for good production and the residual $\mathrm{N}$ available for leaching in the off-season.

\section{Center Pivot-Irrigated Alfalfa Management Field}

Most of the alfalfa field was watered with the same center pivot used for the pivot-irrigated corn. The corner not covered by the pivot and an additional 2.8 ha on the south were irrigated with a tow-line sprinkler system (Fig. 2). Between cuttings, water was applied 
Table 2. Baseline (1990) concentrations in the water table aquifer.

\begin{tabular}{|c|c|}
\hline Analyte & Concentration \\
\hline pH & $6.8 \pm \mathbf{0 . 3}$ \\
\hline Conductance, $\mu \mathrm{S} \mathrm{cm}-1$ & $\mathbf{9 3 0} \pm \mathbf{1 7 0}$ \\
\hline $\mathbf{N O}_{3}-\mathbf{N}, \mathbf{m g ~ \mathbf { L } ^ { - 1 }}$ & $26.1 \pm 4.7$ \\
\hline$\delta^{15} \mathbf{N}-\mathbf{N O}_{3}, \%$ & $6.1 \pm 0.8$ \\
\hline $\mathbf{N H}_{4}-\mathbf{N}, \mathbf{m g ~ L}^{-1}$ & $\mathbf{0 . 1 5} \pm \mathbf{0 . 0 5}$ \\
\hline TKN, $\mathbf{m g ~ \mathbf { L } ^ { - 1 }}$ & $\mathbf{0 . 6 3} \pm \mathbf{0 . 3 9}$ \\
\hline DOC, $\mathbf{m g ~ L}^{-1}$ & $\mathbf{3 . 3} \pm \mathbf{0 . 3}$ \\
\hline $\mathrm{HCO}_{3}^{-}, \mathrm{mg} \mathrm{L}^{-1}$ & $315 \pm 80$ \\
\hline $\mathbf{C l}^{-}, \mathbf{m g ~ L}^{-1}$ & $24 \pm 3$ \\
\hline $\mathbf{S O}_{4}^{2-}, \mathbf{m g ~ \mathbf { L } ^ { - 1 }}$ & $211 \pm 54$ \\
\hline $\mathrm{Na}^{+}, \mathbf{m g ~ L}^{-1}$ & $68 \pm 19$ \\
\hline $\mathbf{K}^{+}, \mathbf{m g ~ L}^{-1}$ & $20 \pm 11$ \\
\hline $\mathbf{C a}^{+2}, \mathbf{m g ~ L}^{-1}$ & $144 \pm 25$ \\
\hline $\mathbf{M g}^{+2}, \mathbf{m g ~ L}^{-1}$ & $29 \pm 5$ \\
\hline
\end{tabular}

based upon precipitation, ET, and the need to keep the field dry during hay harvest. Four cuttings of alfalfa were removed annually.

\section{Hydrogeology}

The unsaturated zone beneath the four management fields is a $1.1-\mathrm{m}$ thick, well-drained, silt loam primarily of Eolian origin overlaying a 4.3-m thick zone of fine to medium-textured sands (Diffendal and Smith, 1996). The predominant soil at the site is a well-drained Hord silt loam (Pachic Hapustoll) with small areas of Hall silt loam (Typic Agriustoll). Both shallow water table and deep confined aquifers exist at the site. The water table aquifer is 14.3 to $17.3-\mathrm{m}$ thick and composed of Quaternary age sand and gravel that overlie an aquitard composed of clayey silt interbedded with clay, sand, and some gravel. Deep boreholes in three corners of the research/demonstration site indicated that the clayey silt is 9 to $20-\mathrm{m}$ thick and forms the upper confining bed of the Ogallala aquifer. The confining clayey silts lie uncomformably on Miocene age sandstone of the Ogallala formation, which rests on impermeable Pierre shale (Diffendal and Smith, 1996).

During the 6-yr investigation, the depth to water in the primary aquifer fluctuated from $\sim 3$ to $\sim 6 \mathrm{~m}$ beneath the land surface, and the direction of horizontal ground water flow switched from east-northeast, to east, and back to east-northeast. A pump test utilizing the irrigation well in the southwest corner of the research/demonstration site indicated that the horizontal hydraulic conductivity in the primary aquifer averages $130 \mathrm{~m} \mathrm{~d}^{-1}$, and the vertical conductivity is $10.4 \mathrm{~m} \mathrm{~d}^{-1}$ (Zlotnik et al., 1993). Using Darcy's Law, a nonretarded solute would be transported beneath the research/demonstration site at an average horizontal rate of $0.55 \mathrm{~m} \mathrm{~d}^{-1}$ and traverse the management fields in a little more than 4 yr. Upward leakage from the Ogallala aquifer to the primary aquifer was not detected during the pump test. Because the Ogallala formation remains $\mathrm{NO}_{3}$ and pesticide-free, it is the domestic water supply for most homes.

\section{Hydrochemistry}

Initially a network of 11 multilevel samplers (MLSs) was installed at the research/demonstration site and in the upgradient buffer. These MLSs provided the baseline data (Table 2) (Spalding et al., 1993) for strategizing the locations of the 31 permanent MLS shown in Fig.
2. Nitrate-N concentrations exceeded the $10 \mathrm{mg} \mathrm{L}^{-1}$ maximum contaminant level (MCL) for potable water (Federal Register, 1975) and were relatively uniform throughout the primary aquifer. Ammonia-N levels were $<0.1 \mathrm{mg} \mathrm{L}^{-1}$. The $\mathrm{N}_{2} / \mathrm{Ar}$ ratios indicated $\mathrm{N}_{2}$ was not in excess of air-saturated water values in most of the sampled cluster wells (Martin et al., 1995), which suggests that denitrification is extremely limited in the shallow ground water. Dissolved organic carbon (DOC) concentrations are too low to be actively involved in significant levels of denitrification and were similar to those reported $20 \mathrm{yr}$ ago (Spalding et al., 1978). The average $\delta^{15} \mathrm{~N}-\mathrm{NO}_{3}$ value $(+6.1 \%$ ) in the primary aquifer is slightly enriched relative to commercial fertilizer leachates (Gormly and Spalding, 1979). The enrichment is believed associated with manure-derived $\mathrm{N}$ from wintering cattle at the site. The relatively uniform $\mathrm{NO}_{3}-\mathrm{N}$ concentrations, low DOC concentrations, uniformly low $\delta^{15} \mathrm{~N}-\mathrm{NO}_{3}$ values, and the lack of excess $\mathrm{N}_{2}$ in the sand and gravel aquifer suggest that the $\mathrm{NO}_{3}$ is not denitrified and acts as a conservative ion.

\section{FIELD PROCEDURES AND LABORATORY METHODS}

The impact of irrigation and fertilizer management on water quality was assessed with pore-water lysimeters and MLSs. Each of the 31 MLSs permits water sampling from as many as 16 different depths throughout the water table aquifer. The MLSs act as a fence to intercept contaminant transport from each of the management fields. Most of the MLSs consist of 8 stainless steel gas-drive samplers, 16 suction sampling tubes, and 4 piezometers (Fig. 3). The suction sampling tubes were placed at the same inlet depths as the gas-drive samplers and also at eight shallower depths. The gas-drive samplers ensured that samples could be collected if the water table declined below the peristaltic pumping level of $\sim 6.5 \mathrm{~m}$. This situation, however, did not occur during the 6-yr study, and all samples were collected from the suction sampling tubes. Each of the 31 MLSs was assembled on site and placed in the borehole in a continuous string.

Two sets of five suction lysimeters (Soil Moisture Equipment model no. 1920) were installed at a depth of $1.4 \mathrm{~m}$ in each field. Within each corn field, the lysimeter sets were separated by 7 rows $(\sim 6.3 \mathrm{~m})$. The lysimeters in each set were $60 \mathrm{~cm}$ apart and aligned along a corn row. Pore water was collected primarily during the irrigation season. A $250-\mathrm{mL}$ side-arm flask was attached to a vacuum pump manifold, and the lysimeter was placed under a vacuum to pull the pore water from the adjacent soils into the porous cup. After about $2 \mathrm{~h}$ the vacuum line was closed, the sample line opened, and the soil pore water transferred from the side-arm flask to a 250-mL polypropylene bottle and acidified with $\mathrm{H}_{2} \mathrm{SO}_{4}$.

Water table measurements and sample collection occurred three times each year: during the preplant period (late March), before irrigation season (late June), and after irrigation season and harvest (early October). Normally preirrigation sampling coincided with the peak in the water table elevation, while postirrigation sampling was associated with the lowest annual water table elevations beneath the fields. Before each sampling event, depth to water was measured in the four piezometers of each MLS using an electronic tape $( \pm 0.61 \mathrm{~cm})$. The measurements were used to contour the water table to determine the direction of ground water flow. The change in direction from east-northeast to due east during the wet 1993 growing season necessitated reevaluating the effectiveness of 


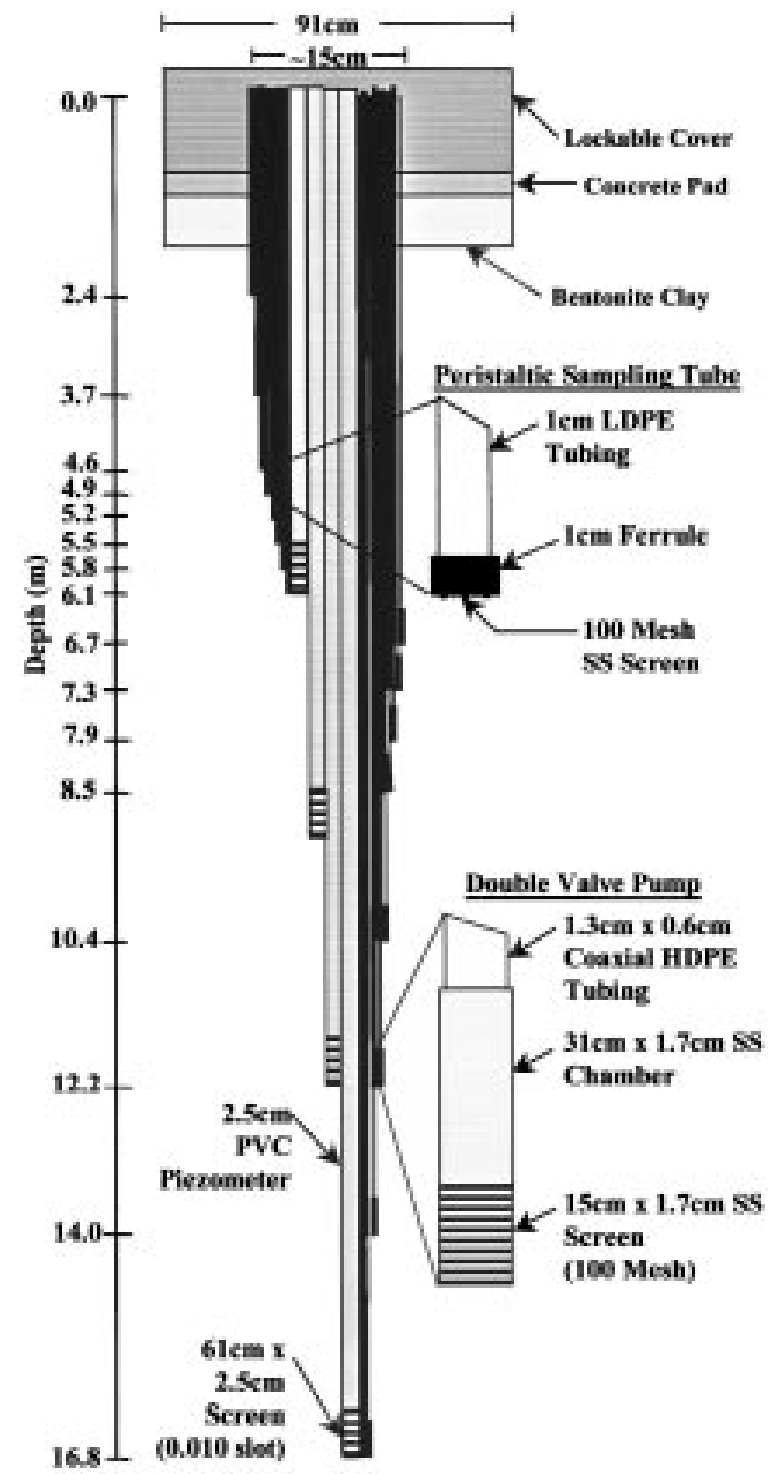

Fig. 3. Multilevel sampler construction.

the MLS locations for intercepting ground water flow downgradient from the pivot-irrigated corn field and resulted in eliminating three MLSs from the downgradient data set (Fig. 2 ). The change in flow direction did not compromise the locations of the MLSs downgradient from the other fields.

After three purge volumes were removed from the suction sampling tubes, conductivity and $\mathrm{pH}$ were measured in the field using portable meters (APHA, 1989), and bicarbonate was analyzed by potentiometric titration with standardized $\mathrm{H}_{2} \mathrm{SO}_{4}$ to $\mathrm{pH}$ of 4.5 using an expanded scale $\mathrm{pH}$ meter (APHA, 1989). Samples for $\mathrm{Na}, \mathrm{K}, \mathrm{Mg}$, and $\mathrm{Ca}$ analysis were collected in 500-mL polyethylene bottles; preserved with nitric acid; and analyzed by atomic absorption spectrophotometry (APHA, 1989). Samples for $\mathrm{NH}_{4}$ and $\mathrm{NO}_{3}$ were collected in polyethylene bottles and acidified with $\mathrm{H}_{2} \mathrm{SO}_{4}$. Ammonium-N concentrations were determined by the automated phenate method, and $\mathrm{NO}_{3}-\mathrm{N}$ concentrations were quantified using the cadmium reduction method (APHA, 1989). Method detection limits for $\mathrm{NH}_{4}-\mathrm{N}$ and $\mathrm{NO}_{3}-\mathrm{N}$ were $0.1 \mathrm{mg} \mathrm{L}{ }^{-1}$. Samples for chloride and sulfate analysis were collected in polyethylene bottles and analyzed by ion chromatography (APHA, 1989). Samples for total Kjeldahl $\mathrm{N}$ analysis were digested with $\mathrm{H}_{2} \mathrm{SO}_{4}$ (APHA, 1989).

Samples for $\delta^{15} \mathrm{~N}-\mathrm{NO}_{3}$ determinations were collected in polyethylene bottles and kept on ice until they reached the laboratory where they were frozen until the time of analysis. Nitrate in the samples was converted to $\left(\mathrm{NH}_{4}\right)_{2} \mathrm{SO}_{4}$ by steam distillation (Bremner and Keeney, 1965) with a modification by Gormly and Spalding (1979). The $\left(\mathrm{NH}_{4}\right)_{2} \mathrm{SO}_{4}$ subsequently was oxidized to $\mathrm{N}_{2}$ in a vacuum preparation system similar to that of Krietler (1975). The purified $\mathrm{N}_{2}$ samples were analyzed with a VG Optima dual inlet isotope ratio mass spectrometer.

Samples for DOC analysis were collected in precombusted 250-mL glass bottles with ground-glass stoppers and preserved with mercuric chloride. The DOC was determined using the wet oxidation method (APHA, 1989). An aliquot of sample was filtered through a binderless, glass fiber filter; acidified; and purged to remove dissolved inorganic $\mathrm{C}$. The DOC was oxidized to $\mathrm{CO}_{2}$ using persulfate and the $\mathrm{CO}_{2}$ was measured with a linearized detector. Each sample was analyzed in triplicate and the average DOC concentration was reported.

Samples for ${ }^{3} \mathrm{He}$ and tritium $\left({ }^{3} \mathrm{H}\right)$ measurements were collected from three MLS locations in spring 1993 (Fig. 2). For the ${ }^{3} \mathrm{He}$ determination, ground water was removed from the piezometers with a positive displacement pump, passed through 0.8 -m copper tubes, and collected by crushing the ends of the tubes. The samples were shipped in trunks and analyzed at the Rare Gas Facility at the University of Rochester by the method of Solomon et al. (1992). Tritium samples were collected in 1-L glass bottles, shipped to the University of Rochester with the ${ }^{3} \mathrm{He}$ samples, electrolytically enriched, and analyzed by scintillation counting techniques.

Precipitation at the site was measured daily with a tipping bucket rain gauge.

Corn yields were determined gravimetrically using a calibrated scale. Grain from 16-row strips across each management field was harvested and weighed to provide a measure of field variability. The $\mathrm{N}$ content of the grain was determined by the Dumas-combustion procedure (Schepers et al., 1989).

\section{RESULTS AND DISCUSSION Ground Water Dating}

Atmospherically derived ${ }^{3} \mathrm{H}$ and its stable daughter $\left({ }^{3} \mathrm{He}\right)$ have been used successfully to date ground water $<50 \mathrm{yr}$ old (Solomon and Sudicky, 1991). The method is especially applicable to shallow unconfined sand and gravel aquifers with characteristically low dispersion rates (Schlosser et al., 1989). Application of the dating technique at the NE-MSEA provides reasonably accurate dates because: (i) the layers are consistently older with depth (Fig. 4); (ii) the ages are quite consistent for water collected from the same depths across the site; and (iii) a concentrated ${ }^{3} \mathrm{H}$ slug indicative of the mid1960 s bomb peak is absent from this active ground water system.

Recharge to an unconfined aquifer is defined as the fluid flux normal to the water table surface and is related to the average linear fluid velocity according to

$$
r=v_{0} \theta
$$

where $r=$ recharge rate $(\mathrm{L} / \mathrm{T}) ; \theta=$ effective porosity $\left(\mathrm{L}^{3} \mathrm{~L}^{-3}\right)$, and $v_{0}=$ component of the average linear velocity normal to the water table (Solomon et al., 1995).

Solomon et al. $(1993,1995)$ have shown that the ${ }^{3} \mathrm{H} /$ ${ }^{3} \mathrm{He}$ age gradient in multilevel piezometer nests can ac- 


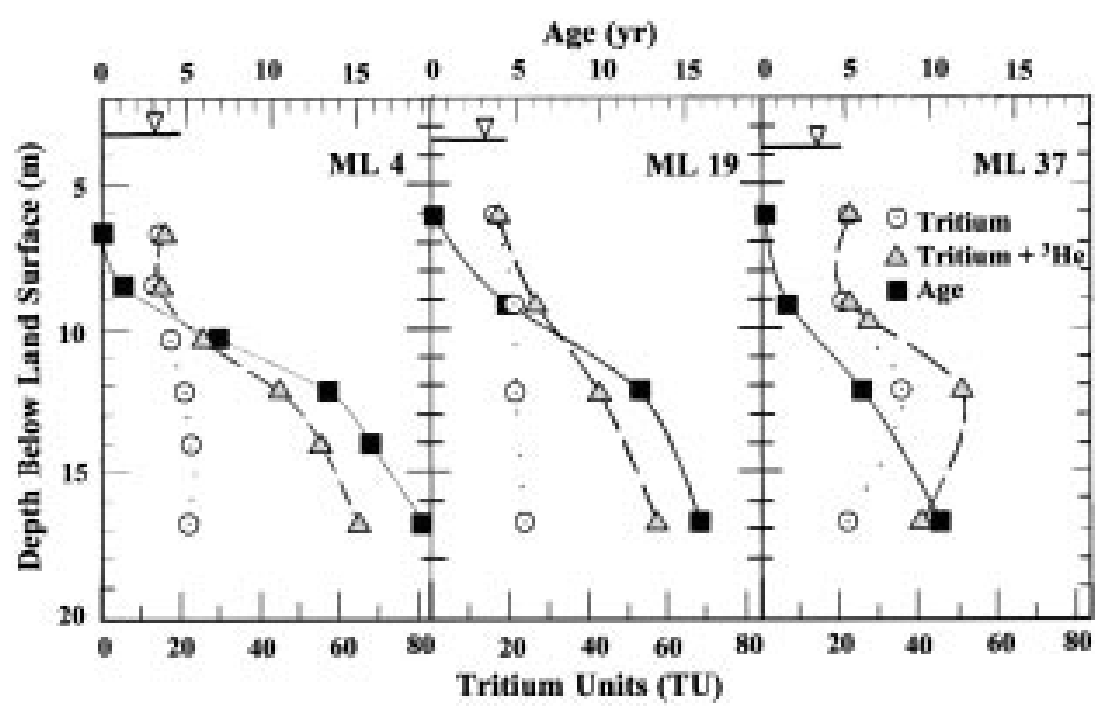

Fig. 4. Ground water age, ${ }^{3} \mathrm{H}$, and ${ }^{3} \mathrm{H}+{ }^{3} \mathrm{He}$ profiles in April 1993 from three piezometer clusters.

curately establish the average recharge to an aquifer. The slopes derived from linear regressions of the age profiles (Fig. 4) using all but the deepest piezometers in each cluster establish a recharge rate for the NE-MSEA. Data from the deepest sampling interval at the aquitardwater table aquifer interface are excluded due to mixing caused by pumping the high-capacity irrigation well, which is screened in the bottom third of the shallow aquifer. Across the site, recharge ranges from $90 \mathrm{~mm}$ $\mathrm{yr}^{-1}$ at the upgradient location (ML-4) to $250 \mathrm{~mm} \mathrm{yr}^{-1}$ downgradient (ML-37) which represents 10 to $20 \%$ of the water input. The highest recharge rate occurs in the well cluster downgradient from the conventional field. It receives the greatest amounts of irrigation water (Table 1 ), and recharge is further enhanced by the blockedend furrows (Fig. 2).

Investigations by Solomon et al. (1992, 1993) have shown that gas exchange at the water table, the enhanced diffusion coefficient for $\mathrm{He}$, and the seasonal nature of recharge cause the ${ }^{3} \mathrm{H} /{ }^{3} \mathrm{He}$ clock to start at or near the seasonal low water table. At the NE-MSEA, the low water table normally occurs in early autumn and coincides with the harvest. Higher than normal precipitation between October 1992 and early summer 1993 caused a rise in the water table from $5.5 \mathrm{~m}$ to $\sim 4 \mathrm{~m}$. In spring 1993 the shallowest sample from each piezometer cluster had an ${ }^{3} \mathrm{He} /{ }^{4} \mathrm{He}$ ratio indistinguishable from airsaturated water. The estimated ${ }^{3} \mathrm{H} /{ }^{\beta} \mathrm{He}$ age of $0.0 \pm 0.5$ $\mathrm{yr}$ in these shallow samples supports their origins as seasonal recharge.

\section{Nitrate-Nitrogen Profiles}

Fall 1991 and $1992 \mathrm{NO}_{3}-\mathrm{N}$ concentration profiles of $\sim 1000$ samples collected from the 31 MLSs (Fig. 5) show that the average concentrations were consistently high $\left(28.5 \pm 5.5 \mathrm{mg} \mathrm{L}^{-1}\right)$ regardless of depth in the unconfined aquifer or areal location. The uniformly high concentrations with depth do not conform to profiles commonly reported in the literature, which, almost without exception, describe decreasing $\mathrm{NO}_{3}-\mathrm{N}$ concentrations with increased depth (Hallberg, 1989; Libra et al., 1993; Spalding and Exner, 1993; Bohlke and Denver, 1995). The initial invariable $\mathrm{NO}_{3}$ concentrations with depth appear related to a relatively homogeneous aquifer matrix, constant upgradient agricultural sources, and mixing that results from extensive pumping of large-capacity irrigation wells screened in the bottom third of the shallow aquifer (Zlotnik et al., 1995).

In response to heavy rainfall, $\mathrm{NO}_{3}-\mathrm{N}$ concentrations in the fall 1993 profile declined $\sim 10$ to $20 \mathrm{mg} \mathrm{L}^{-1}$ and concentrations in many samples from the top $3 \mathrm{~m}$ of the aquifer declined below the MCL (Fig. 5). Nitrate-N concentrations $(n=85)$ in the uppermost $3 \mathrm{~m}$ averaged $11.6 \pm 6.9 \mathrm{mg} \mathrm{L}^{-1}$. The effect of the relatively low $\mathrm{NO}_{3}$ recharge is clearly shown 3 to $6 \mathrm{~m}$ below the water table, where there is a linear increase $(r=0.96, n=8)$ in the average concentration from approximately 12 to $25 \mathrm{mg}$ $\mathrm{NO}_{3}-\mathrm{N} \mathrm{L}^{-1}$. The precipitous decrease in average $\mathrm{NO}_{3}-\mathrm{N}$ concentrations in the top $6 \mathrm{~m}$ of the aquifer accompanied a $2.4-\mathrm{m}$ rise in the water table. Thus, infiltration of precipitation with relatively low concentrations of $\mathrm{NO}_{3}-\mathrm{N}$ significantly improved the quality of the shallow ground water.

Improvements in $\mathrm{NO}_{3}$ quality from the 1993 recharge were limited to the upper ground water, and $\mathrm{NO}_{3}-\mathrm{N}$ concentrations in water deeper than $9 \mathrm{~m}$ did not decrease (Fig. 5). This deeper water with a ground water residence time $>5 \mathrm{yr}$ originated as infiltrate from upgradient fields and was laterally transported beneath the NE-MSEA at $\sim 0.5 \mathrm{~m} \mathrm{~d}^{-1}$. Thus, the first $3 \mathrm{yr}$ of ground water $\mathrm{NO}_{3}-\mathrm{N}$ data confirm that seasonal changes in water quality brought about by recent recharge can clearly be detected in shallow ground water $(\leq 6 \mathrm{~m})$ and that the depth of impact is limited by the volume of recharge. While the 1993 climatic conditions were anomalous, the $\mathrm{NO}_{3}-\mathrm{N}$ concentrations in municipal wells in nearby Wood River and Shelton also were significantly reduced during another very wet spring in 1967 (Spalding, 1975). The data indicate that although extremely wet years and floods can cause agricultural and urban 

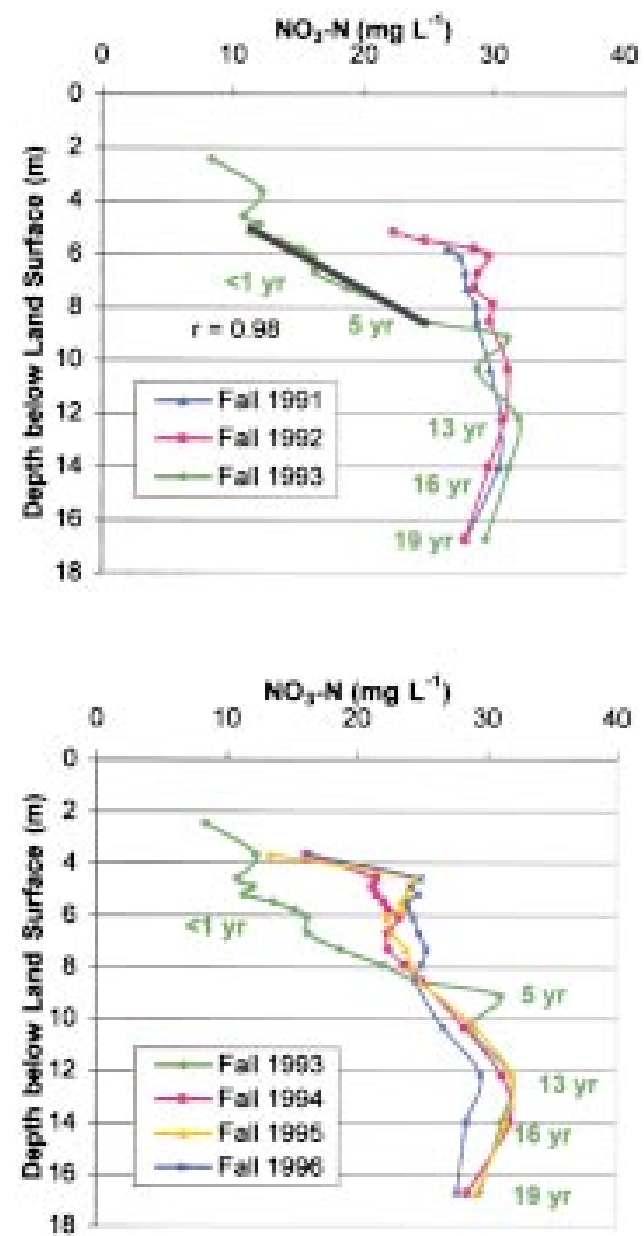

Fig. 5. Vertical profiles of ground water $\mathrm{NO}_{3}-\mathrm{N}$ concentrations, fall 1991-1996, with regression line for $\mathrm{NO}_{3}-\mathrm{N}$ concentration vs. depth below land surface in the mixing zone and 1993 ground water ages.

disasters, the recharge can be highly beneficial to shallow ground water quality.

For 3 successive years after 1993, average $\mathrm{NO}_{3}$ concentrations in the shallow ground water rose (Fig. 5). Increases in the average $\mathrm{NO}_{3}-\mathrm{N}$ concentration to approximately $25 \mathrm{mg} \mathrm{L}^{-1}$ in 1996 indicate concentrations were approaching premanagement levels of $30 \mathrm{mg} \mathrm{L}^{-1}$ under some management fields.

Each fall, $\mathrm{NO}_{3}$ levels were lowest in the shallowest ground water sampler (Fig. 5), indicating that irrigation water had flushed most of the mobile $\mathrm{NO}_{3}$ from the vadose zone, and that $\mathrm{NO}_{3}$ concentrations in the most recent recharge were less than in the irrigation water. The latter is partially the result of uptake of $\mathrm{NO}_{3}$ from irrigation water during the latter part of the irrigation season.

\section{Shallow Ground Water Nitrate-Nitrogen Loading}

An understanding of the controlling mechanisms and associations involved in long-term nonpoint-source shallow ground water loading are fundamental to the implementation of scientifically based management practices. During the $6 \mathrm{yr}$, seasonal average $\mathrm{NO}_{3}-\mathrm{N}$ concentrations in the shallow $(\leq 1.5 \mathrm{~m})$ ground water at the fences downgradient of the management fields were correlated with water levels and generally were cyclic (Fig. 6a and b). With the exception of 1993, when above normal precipitation resulted in a rising water table, the water table usually declined between summer and fall measurements, and $\mathrm{NO}_{3}-\mathrm{N}$ concentrations in most shallow ground water increased. The declines are caused by irrigation withdrawals, which begin in mid-June and generally continue through the first week of September. The irrigation water, which is primarily pumped from the bottom third of the water table aquifer and has a concentration of $30 \mathrm{mg} \mathrm{NO}-\mathrm{N} \mathrm{L}^{-1}$, as well as the $\mathrm{NO}_{3}$ in the irrigation water, are partially utilized by the crop. The returning irrigation water leaches additional nitrate from the soils and transports it to the aquifer. Consequently, irrigation returns tend to increase $\mathrm{NO}_{3}-\mathrm{N}$ concentrations in the shallow ground water. Hotter and drier growing seasons like 1994 require the application of more irrigation water with a resultant increase in shallow ground water $\mathrm{NO}_{3}$ loading.

Differences in $\mathrm{N}$ leaching beneath the management fields can be further elucidated by the pore-water $\mathrm{NO}_{3}$ concentrations (Fig. 6a and b). Pore-water $\mathrm{NO}_{3}-\mathrm{N}$ concentrations reflect the timely monitoring afforded by lysimeters, which make the instrumentation useful in predicting trends in shallow ground water $\mathrm{NO}_{3}$ concentrations (Watts et al., 1997). Concentrations in the pore water, however, can be significantly more variable than in the shallow ground water where pore-water inputs are attenuated.

Shallow ground water quality downgradient of each management field was impacted by irrigation and nutrient management strategies as evidenced by discernable differences in correlation coefficients and the magnitude of the standard deviations of the $\mathrm{NO}_{3}-\mathrm{N}$ concentrations (Fig. 6a and b). The $R$ values for seasonally averaged $\mathrm{NO}_{3}-\mathrm{N}$ concentrations vs. seasonally averaged water levels ranged from +0.28 for the surge-irrigated field (Fig. 6a) to +0.92 for the center pivot-irrigated corn field (Fig. 6b). Since physical characteristics of the unsaturated zone beneath the fields are similar, $\mathrm{NO}_{3}-\mathrm{N}$ concentrations downgradient of each management field likely reflect not only the different water and nutrient practices, but also the presence of hot spots associated with sites of deep preferential percolation. The regression plots showed more variability in $\mathrm{NO}_{3}-\mathrm{N}$ loading occurred at the surge-irrigated field than at the conventional furrow-irrigated field. The most uniform $\mathrm{NO}_{3}$ fluxes occurred beneath the pivot-irrigated corn field where as much as $84 \%$ of the variability in $\mathrm{NO}_{3}-\mathrm{N}$ concentrations was associated with water level. The higher average $\mathrm{NO}_{3}-\mathrm{N}$ concentrations and the larger fluctuations in $\mathrm{NO}_{3}-\mathrm{N}$ concentrations associated with both furrow irrigation practices suggest that centerpivot application of irrigation water is the vastly superior practice for controlling $\mathrm{NO}_{3}$ leaching.

Peak concentrations in pore-water $\mathrm{NO}_{3}$ were especially pronounced beneath both furrow-irrigated fields 


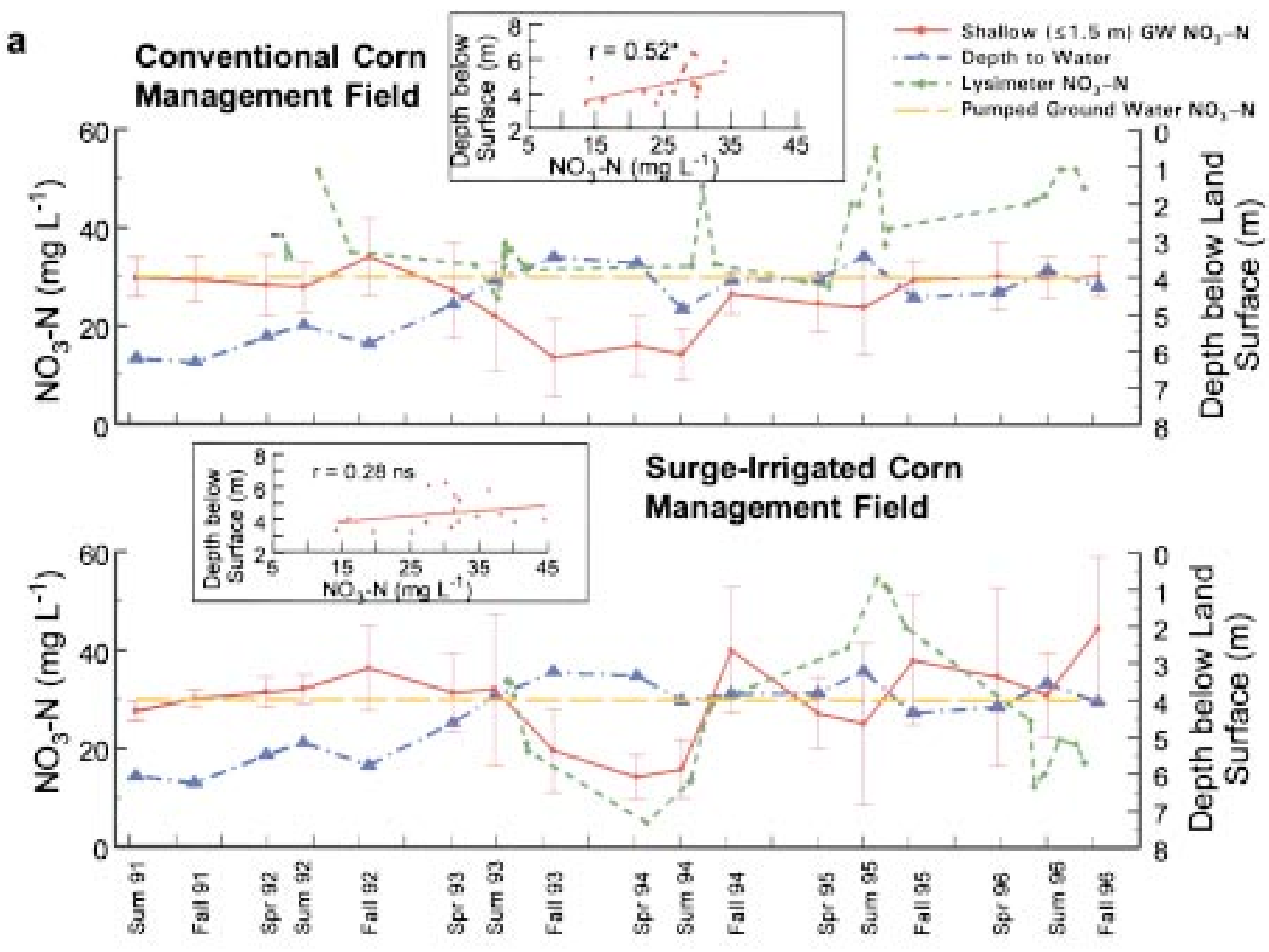

b
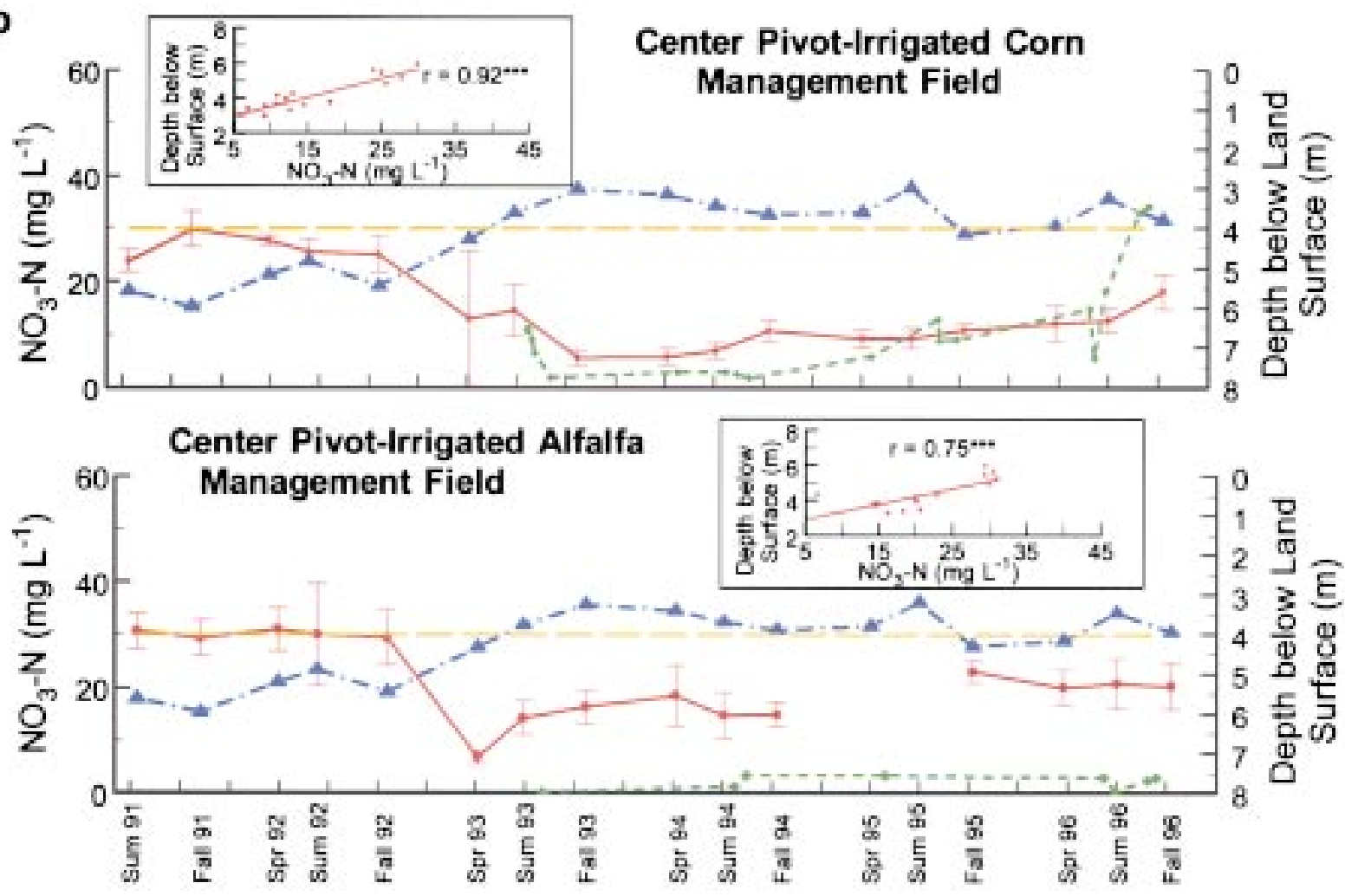

Fig. 6. Seasonal plots of average pore-water and shallow ground water $\mathrm{NO}_{3}-\mathrm{N}$ concentrations and depth to water with inset plots of the regression line of the seasonal average shallow ground water $\mathrm{NO}_{3}-\mathrm{N}$ concentrations vs. depth to the water table at the $(a)$ furrow-irrigated and $(b)$ pivot-irrigated management fields. Levels of statistical significance of $r$ values are as follows: $n s=$ not significant, $*=$ significant at $5 \%$ level, and $* * *=$ significant at $0.1 \%$ level. 
during the 1994, 1995, and 1996 growing seasons (Fig. 6a). Although Cahoon et al. (1995) documented that deep percolation occurred at the upper end of furrowirrigated fields and also behind diked end-rows at the lower end of conventionally irrigated fields, these $\mathrm{NO}_{3}^{-}$leachates were detected in the center of the fields (Fig. 2). Average pore-water $\mathrm{NO}_{3}-\mathrm{N}$ concentrations rose approximately $20 \mathrm{mg} \mathrm{L}^{-1}$ at both fields (Fig. 6a) before the fall 1994 ground water sampling when concentrations rebounded to near or above the initial project levels of $30 \mathrm{mg} \mathrm{NO}-\mathrm{N} \mathrm{L}^{-1}$ and remained at that level for the duration of the study. At the surge-irrigated field, deep percolation of $\mathrm{NO}_{3}-\mathrm{N}$ appeared enhanced by the preferential leaching of fertigation-applied $\mathrm{N}$ when the highly concentrated water ponded in furrows choked by storm-downed corn and weeds. Nitrate concentrations in ground water collected downgradient from the surge-irrigated field after the 1995 and 1996 irrigation seasons suggest that applying all or part of the $\mathrm{N}$ fertilizer requirement as sidedress was also detrimental to water quality (Fig. 6a). The fence downgradient of the conventional field first intercepts percolate from diked end-rows (Fig. 2) that were flooded during periods of excessive irrigation in 1996. The upgradient highly concentrated pore water appears to have been attenuated by the $30 \mathrm{mg} \mathrm{NO}-\mathrm{N} \mathrm{L}^{-1}$ recharge from excess irrigation water at the diked end-rows during ground water transport to the downgradient fence.

In contrast to the post-1993 rapid rebound in $\mathrm{NO}_{3}$ at the fences downgradient of the furrow-irrigated fields, average shallow ground water concentrations at the pivot-irrigated corn field were considerably $<10 \mathrm{mg}$ $\mathrm{NO}_{3}-\mathrm{N} \mathrm{L}^{-1}$, and pore-water $\mathrm{NO}_{3}-\mathrm{N}$ concentrations remained $<5 \mathrm{mg} \mathrm{L}^{-1}$ through spring 1995 . Only after operator error resulted in a preplant application of an extra $22 \mathrm{~kg} \mathrm{~N} \mathrm{ha}^{-1}$ before heavy spring rains in 1996 did the $\mathrm{NO}_{3}$ levels in the pore water increase significantly (Fig. $6 \mathrm{~b}$ ). The rise in pore-water $\mathrm{NO}_{3}-\mathrm{N}$ concentrations was accompanied by a marked increase in shallow ground water $\mathrm{NO}_{3}-\mathrm{N}$. Thus, a small overapplication of fertilizer $\mathrm{N}$ clearly was detected in the shallow ground water and caused $\mathrm{NO}_{3}$ concentrations to rapidly exceed the MCL.
By design there were large discrepancies in total $\mathrm{N}$ applied to the conventional field compared with the surge and pivot-irrigated management fields (Fig. 7). On the other hand, the total amount of $\mathrm{N}$ applied to the surge and center pivot-irrigated management fields was quite similar. Differences in the amount of applied $\mathrm{N}$ were caused mostly by differences in the quantity of applied water. When irrigating corn with $\mathrm{NO}_{3}$-contaminated water, leaching is limited by reducing fertilizer applications below recommendations, thereby causing the crop to extract $\mathrm{N}$ from the water. Hergert et al. (1995) suggested reducing the $\mathrm{N}$ recommendation for furrow-irrigated corn by the amount of $\mathrm{N}$ in $230 \mathrm{~mm}$ of irrigation water, which is less than the minimum amount of water applied by most conventional irrigators during the crop's rapid $\mathrm{N}$ uptake period that ends about 1 August. Irrigation applications on the conventional management field far exceeded $230 \mathrm{~mm}$ in all but 1993 (Table 1), the only year in which there was a reduction in shallow ground water $\mathrm{NO}_{3}$ concentrations. Nitrogen fertilizer applications also exceeded recommendations in all but 1993. The 6-yr total fertilizer $\mathrm{N}$ application exceeded the amount of $\mathrm{N}$ removed in the grain by 438 $\mathrm{kg} \mathrm{ha}^{-1}$. Irrigation water in excess of the prescribed 230 $\mathrm{mm}$ was applied in 4 of $6 \mathrm{yr}$ on the surge-irrigated field (Table 1); however, only in 1991 was this total exceeded before the end of the rapid $\mathrm{N}$ uptake period. Although $\mathrm{N}$ fertilizer was applied below or at recommended rates, the 6-yr total fertilizer $\mathrm{N}$ application exceeded the amount removed in the grain by $129 \mathrm{~kg} \mathrm{ha}^{-1}$. In theory, the expected reduction in $\mathrm{NO}_{3}-\mathrm{N}$ leaching from the surge-irrigated field should have resulted in less adverse impact on shallow ground water than the conventional field. In practice, it did not. The surge technology was unable to adequately control leaching of $\mathrm{N}$ fertilizer, even when applied by split application for fertigation. In only the first year did irrigation water applied at the pivot field exceed $230 \mathrm{~mm}$ (Table 1). Total applied $\mathrm{N}$ was less than or equal to the recommended amount during the first $4 \mathrm{yr}$ (Fig. 7). During the $6 \mathrm{yr}$, total applied $\mathrm{N}$ was only $80 \mathrm{~kg} \mathrm{~N} \mathrm{ha}^{-1}$ in excess of that removed in

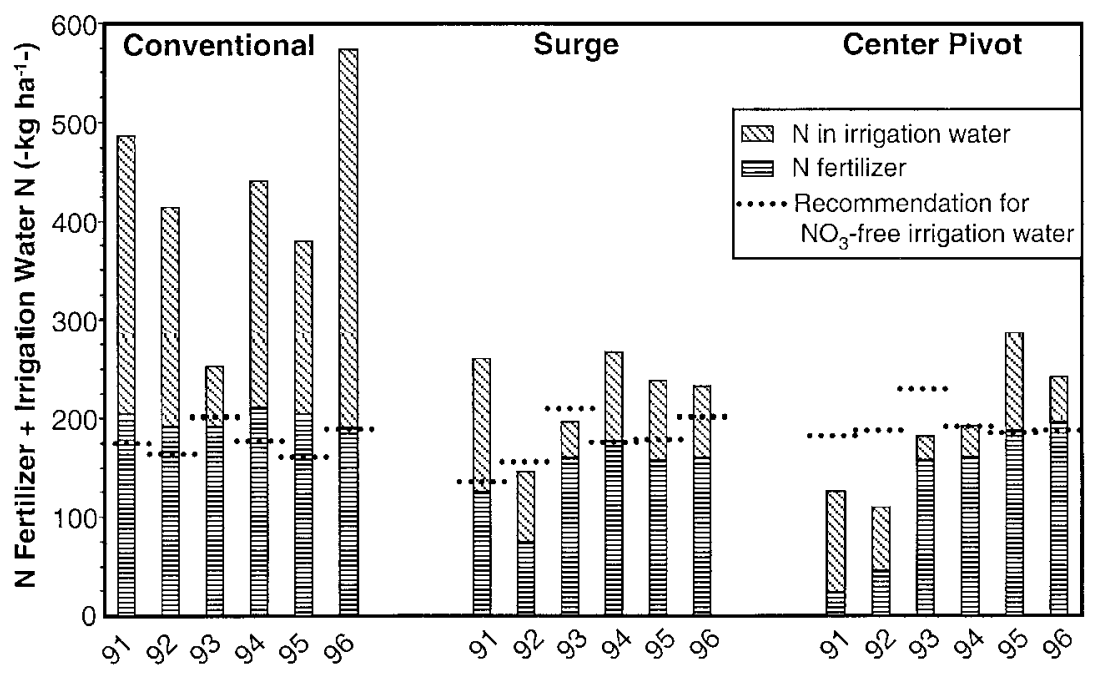

Fig. 7. Recommended $\mathbf{N}$ fertilizer application and $\mathbf{N}$ inputs from fertilizer and irrigation water for corn management fields. Recommended $N$ for an expected yield of $12.6 \mathrm{Mg} \mathrm{ha}^{-1}$ is based upon $2 \%$ soil organic matter and residual $\mathrm{NO}_{3}-\mathrm{N}$ in the upper $0.9 \mathrm{~m}$ of the root zone. 
the grain, and the $\mathrm{N}$ application was $32 \%$ less than that on the conventional field. Thus, significant improvement in shallow ground water quality occurred only beneath the pivot-irrigated corn field.

Most year-to-year variability in grain yield was directly associated with weather (Table 2). Yields in 1992 and 1996 were outstanding while those in 1991 and 1995 were good. During the 1993 growing season, cloudy weather, excessive rainfall, and stalk breakage caused by high winds reduced corn yields to $\sim 30 \%$ below average, while hail and high winds during the 1994 growing season stripped and knocked down the corn, reducing yields $\sim 40 \%$.

Even when a technology successfully reduces $\mathrm{NO}_{3}$ leaching, farmer acceptance largely depends on yield. Yield variations ascribed to differences in management activities were not large and were sometimes misleading. The location of a tree-row partially shielded the furrowirrigated corn, but not the center-pivot irrigated corn, from damage by wind and hail in 1994. Since the damage was preferential and not related to management differences, the yields were not used in the average yield calculations (Table 1). In 1992 the 15\% reduction in yield on the pivot-irrigated field as compared to the conventional field was related to spatial variability in residual soil $\mathrm{N}$ and could be overcome with better knowledge of soil nuances and the use of precision fertilizer applications. An $\sim 6 \%$ reduction in the 5-yr average yield for the pivot-irrigated management field relative to the conventional field should not adversely affect farmer acceptance, could be averted with a better understanding of the system, and was partially offset by lower fertilizer expense.

Nitrogen fertilizer was not applied to the irrigated alfalfa; however, the $\mathrm{NO}_{3}-\mathrm{N}$ levels in the downgradient shallow ground water exceeded the MCL during all but one sampling period (Fig. 6b). The field was converted from continuous corn to a normal $\mathrm{N}_{2}$-fixing alfalfa in 1990. Normal $\mathrm{N}_{2}$-fixing cultivars remove about one-third less $\mathrm{NO}_{3}$ from subsoils than do nonfixing $\mathrm{N}_{2}$ cultivars (Blumenthal and Russelle, 1996). Reported interest in using alfalfa to remediate $\mathrm{NO}_{3}$-contaminated soils has continued for the past $40 \mathrm{yr}$ (Allos and Bartholomew, 1959; Stewart et al., 1968; Peterson and Russelle, 1991). Alfalfa can be very deep-rooted (Jodari-Karimi et al., 1983) and has been reported to remove water and $\mathrm{N}$ from 4-m deep capillary fringe zones (Lipps and Fox, 1964). By Fall 1992, the 3 yr old alfalfa roots probably reached the capillary fringe about $6 \mathrm{~m}$ beneath the surface. After the initial vadose zone inundation in Spring 1993, water table rises of $>2 \mathrm{~m}$ during the next three successive sampling periods were accompanied by increases in average downgradient $\mathrm{NO}_{3}-\mathrm{N}$ (Fig. 6b). The number of lysimeter samples collected beneath the alfalfa field was sparse because there was insufficient pore water for $\mathrm{NO}_{3}-\mathrm{N}$ analysis during several sampling periods. However, when the volume of pore water was adequate, the $\mathrm{NO}_{3}-\mathrm{N}$ concentrations did not exceed $5 \mathrm{mg}$ $\mathrm{L}^{-1}$. Thus, the $\mathrm{NO}_{3}$ in the irrigation return flows appears to be removed in the shallow root zone and is not a significant contributor to the ground water contamina- tion. This suggests that the $\mathrm{N}$ source must be deeper in the vadose zone, where water-logged alfalfa roots and nodules decayed and released substantial amounts of $\mathrm{N}$ after the water table rose. In alfalfa-dominated areas, shallow ground water $\mathrm{NO}_{3}$ contamination has been reported by the Minnesota Pollution Control Agency (1998) and Robbins and Carter (1980), who reported significant levels of $\mathrm{NO}_{3}$ from the mineralization of root material.

\section{CONCLUSIONS}

Well-designed and instrumented sites with MLSs give a clear indication of the impact of management changes on nonpoint-source-impacted shallow ground water quality. Nitrate concentrations in samples collected from lysimeters and MLS networks together with ${ }^{3} \mathrm{H} /$ ${ }^{3} \mathrm{He}$ age dating of water at the Nebraska Management Site Evaluation Area indicated that weekly movement of $\mathrm{N}$ in the unsaturated zone was detectable, as were season-to-season changes in shallow ground water $\mathrm{NO}_{3}$ concentrations. Fluctuations in pore-water $\mathrm{NO}_{3}$ concentrations were more extreme than those in the more integrated shallow ground water.

The results demonstrate that the conversion from furrow to well-managed sprinkler irrigation would significantly benefit shallow ground water quality in the central Platte region and other corn-growing areas in the western USA. Uniform water application and the ability to apply supplemental $\mathrm{N}$ on an as-needed basis through fertigation substantially controlled $\mathrm{NO}_{3}$ leaching beneath the pivot-irrigated management field. Farmers should be encouraged to adopt center pivot or linear spray irrigation techniques and best nutrient and water management practices to lower and maintain ground water $\mathrm{NO}_{3}$ at or near compliance levels. It is recognized that water quality improvements will require a serious effort and probably include strategies for setting slightly lower yield goals and increasing crop use of $\mathrm{NO}_{3}$ in irrigation water.

Surge irrigation was unable to satisfactorily limit $\mathrm{NO}_{3}-\mathrm{N}$ leaching, negating any inherent water quality benefits of applying less water and $\mathrm{N}$.

Although the sprinkler-irrigated alfalfa field did not receive $\mathrm{N}$ fertilizer during the 6 -yr study, $\mathrm{NO}_{3}$ concentrations in the shallow MLSs downgradient of the field showed there was significant leaching. The leaching appears to be associated with the age of the alfalfa and the timing of the rise in the water table that initiated root and nodule decay, releasing $\mathrm{N}$ to the shallow ground water.

\section{ACKNOWLEDGMENTS}

The authors are grateful to Jeff Toavs and Tom Papiernik for assistance in the installation and sampling of the MLSs and to Patrick Larsen and Dorothy Harrell for computer drafting the figures. The project was funded by USDA-CSRS. The Water Sciences Laboratory was supported with funds from the Nebraska Research Initiative. The authors are deeply indebted to Loran Niemack, the cooperating farmer. This manuscript has been assigned Journal Series no. 13038, Agricultural Research Division, University of Nebraska. 


\section{REFERENCES}

Allos, H.F., and W.V. Bartholomew. 1959. Replacement of symbiotic fixation by available nitrogen. Soil Sci. 87:61-66.

American Public Health Association. 1989. Standard methods for the examination of water and wastewater. 17th ed. APHA, Washington, DC.

Anderson, H.H. 1989. Effects of agriculture on quality of water in surficial sand-plain aquifers in Douglas, Kandiyohi, Pope, and Stearns counties, Minnesota. Water Resour. Invest. U.S. Geol. Surv. 87-4040.

Blumenthal, J.M., and M.P. Russelle. 1996. Subsoil nitrate uptake and symbiotic dinitrogen fixation by alfalfa. Agron. J. 88:909-915.

Bohlke, J.K., and J.M. Denver. 1995. Combined use of groundwater dating, chemical, and isotopic analyses to resolve the history and fate of nitrate contamination in two agricultural watersheds, Atlantic coastal plain, Maryland. Water Resour. Res. 31:2319-2339.

Bremner, J.M., and D.R. Keeney. 1965. Steam distillation method for determination of ammonium, nitrate, and nitrite. Anal. Chim. Acta 32:485-495.

Cahoon, J.E., P. Mandel, and D.E. Eisenhauer. 1995. Management recommendations for sloping blocked-end furrow irrigation. Appl. Eng. Agric. 11:527-533.

Diffendal, R.F., and F.A. Smith. 1996. Geology beneath the primary Management Systems Evaluation Area (MSEA) site southwest of Shelton, Buffalo County, Nebraska. NE Geol. Surv. Rep. Invest. 11. Conserv. and Survey Div., Univ. of Nebraska, Lincoln, NE.

Federal Register. 1975. National Interim Primary Drinking Water Standards. Fed. Regist. 40:59566-59588.

Gormly, J.R., and R.F. Spalding. 1979. Sources and concentrations of nitrate-nitrogen in ground water of the Central Platte Region, Nebraska. Ground Water 17:291-301.

Hallberg, G.R. 1989. Nitrate in ground-water in the United States. p. 35-74. In R.F. Follett (ed.) Nitrogen management and groundwater protection. Elsevier, Amsterdam.

Hergert, G.W., R.B. Ferguson, and C.A. Shapiro. 1995. Fertilizer suggestions for corn. NebGuide Rep. G74-174-A. Coop. Ext., Inst. of Agric. and Nat. Resour., Univ. of Nebraska, Lincoln, NE.

Jodari-Karimi, F., V. Watson, H. Hodges, and F. Whisler. 1983. Root distribution and water use efficiency of alfalfa as influenced by depth of irrigation. Agron. J. 75:207-211.

Kreitler, C.W.1975. Determining the source of nitrate in ground water by nitrogen isotope studies. Bureau of Economic Geol. Rep. of Invest. 83, Univ. Texas, Austin, TX.

Libra, R.D., G.R. Hallberg, K.D. Rex, B.C. Kross, L.S. Seigley, M.A. Culp, R.W. Field, D.J. Quade, M. Selim, B.K. Nations, N.H. Hall, L.A. Etre, J.K. Johnson, H.F. Nicholson, S.L. Berberich, and K.L. Cherryholmes. 1993. The Iowa state-wide rural well water survey: June 1991, repeat sampling of the 10\% subset. Tech. Inf. Ser. 26. Iowa Dep. of Nat. Resour., Iowa City, IA.

Lipps, R.C., and R.L. Fox. 1964. Root activity of sub-irrigated alfalfa as related to soil moisture, temperature, and oxygen supply. Soil Sci. 97:4-12.

Madison, R.J., and J.O. Brunett. 1985. Overview of the occurrence of nitrate in ground water of the United States. U.S. Geol. Surv. Water Supply Pap. 2275.

Martin, D.L., and D.G. Watts. 1997. Effect of irrigation and management practices on crop production and nitrate leaching. p. 26-43 In J. Shaack et al. (ed.) Best management practices for irrigated agriculture and the environment. Proc., U.S. Committee on Irrigation and Drainage, Fargo, ND. 16-19 July 1997. U.S. Committee on Irrigation and Drainage, Denver, CO.

Martin, G.E., D.D. Snow, E. Kim, and R.F. Spalding. 1995. Simultaneous determination of argon and nitrogen. Ground Water 33 781-785.

Minnesota Pollution Control Agency. 1998. Water quality in the upper fifteen feet of a shallow sand aquifer in a variable land use setting. December. Minnesota Pollution Control Agency, Environmental Outcomes Div., St. Paul, MN.

Musick, J.T., J.D. Walker, A.D Schneider, and F.B. Pringle. 1987. Seasonal evaluation of surge flow irrigation for corn. App. Eng. Agric. 3:247-251

Peterson, T.A., and M.P. Russelle. 1991. Alfalfa and the nitrogen cycle in the Corn Belt. J. Soil Water Conserv. 46:229-235.

Power, J.F., and J.S. Schepers. 1989. Nitrate contamination of groundwater in North America. Agric. Ecosyst. Environ. 26:165-187.

Robbins, C.W., and D.L. Carter. 1980. Nitrate-nitrogen leached below the root zone during and following alfalfa. J. Environ. Qual. 9:447450.

Schepers, J.S., D.D. Francis, and M.T. Thompson. 1989. Simultaneous determination of total $\mathrm{C}$, total $\mathrm{N}$, and ${ }^{15} \mathrm{~N}$ on soil and plant material Commun. Soil Sci. Plant Anal. 20:949-959.

Schepers, J.S., G.E. Varvel, and D.G. Watts. 1995. Nitrogen and water management strategies to reduce nitrate leaching under irrigated maize. J. Contam. Hydrol. 20:227-239.

Schlosser, P., M. Stute, C. Sonntag, and K.O. Münnich. 1989. Tritiogenic ${ }^{3} \mathrm{He}$ in shallow groundwater. Earth Planet. Sci. Lett. 94:245256.

Solomon, D.K., R.J. Poreda, P.G. Cook, and A. Hunt. 1995. Site characterization using ${ }^{3} \mathrm{H} /{ }^{3} \mathrm{He}$ ground-water ages, Cape Cod, MA Ground Water 33:988-996.

Solomon, D.K., R.J. Poreda, S.L. Schiff, and J.A. Cherry. 1992. Tritium and helium 3 as groundwater age tracers in the Borden aquifer. Water Resour. Res. 28:741-755.

Solomon, D.K., S.L. Schiff, R.J. Poreda, and W.B. Clarke. 1993. A validation of the ${ }^{3} \mathrm{H} /{ }^{3} \mathrm{He}$ method for determining groundwater recharge. Water Resour. Res. 29:2951-2962.

Solomon, D.K., and E.A. Sudicky. 1991. Tritium and helium 3 isotope ratios for direct estimation of spatial variations in groundwater recharge. Water Resour. Res. 27:2309-2319.

Spalding, R.F. 1975. Effects of land use and river seepage on groundwater quality in Hall County, Nebraska. Nebraska Water Surv. Pap. 38. Conserv. and Survey Div., Univ. of Nebraska, Lincoln, NE.

Spalding, R.F., M.E. Burbach, R.F. Diffendal, Jr., M.E. Exner, and T.D. Papernik. 1993. Analysis of $\mathrm{NO}_{3}-\mathrm{N}$ distribution beneath Nebraska MSEA blocks. p. 314-317. In Agricultural research to protect water quality: Proc., Soil and Water Conservation Soc., Minneapolis, MN. 21-24 Feb. 1993. Soil and Water Conserv. Soc., Ankeny, IA.

Spalding, R.F., and M.E. Exner. 1993. Occurrence of nitrate in groundwater: A review. J. Environ. Qual. 22:392-402.

Spalding, R.F., J.R. Gormly, and K.G. Nash. 1978. Carbon contents and sources in ground waters of the Central Platte Region in Nebraska. J. Environ. Qual. 7:428-434.

Stewart, B.A., F.G. Viets, and G.L. Hutchinson. 1968. Agriculture's effect on nitrate pollution of ground water. J. Soil Water Conserv. 23:13-15.

Supalla, R.J., R.A. Selley, S. Bredeweg, and D.G. Watts. 1995. Adoption of nitrogen and water management practices to improve water quality. J. Soil Water Conserv. 50:77-82.

Watts, D.G., J.R. Schepers, and R.F. Spalding. 1997. Field-scale evaluation of water and nitrogen management impacts on ground water quality. p. 73-88. In J. Shaack et al. (ed.) Best Management Practices for Irrigated Agriculture and the Environment: Proc., U.S Committee on Irrigation and Drainage, Fargo, ND. 16-19 July. U.S. Committee on Irrigation and Drainage, Denver, CO.

Zlotnik, V.A., M.E. Burbach, M.E. Exner, and R.F. Spalding. 1995. Well sampling for agrichemicals in high capacity systems. J. Soil Water Conserv. 50:95-101.

Zlotnik, V.A., R.F. Spalding, M.E. Exner, and M.E. Burbach. 1993 Sampling of non-point source contamination in high-capacity wells. Water Sci. Technol. 28:409-413. 